\title{
Endothelial progenitor cells derived from the peripheral blood of halfpipe- snowboarding athletes display specific functional properties
}

\author{
Y.H. Zhao ${ }^{1 *}$, J.C. Kan ${ }^{1 *}$, Y.F. Wang1, W.J. Guan ${ }^{2}$ and Z.Q. Zhu ${ }^{1}$ \\ ${ }^{1}$ Sport Science College, Harbin Institute of Physical Education, Nangang District, \\ Harbin, Heilongjiang Province, China \\ ${ }^{2}$ Institute of Animal Science, Chinese Academy of Agricultural Sciences, \\ Haidian District, Beijing, China \\ *These authors contributed equally to this study. \\ Corresponding authors: Z.Q. Zhu / W.J. Guan \\ E-mail: zhiqiangzhu999@163.com / weijunguan301@gmail.com
}

Genet. Mol. Res. 15 (4): gmr15047026

Received August 10, 2016

Accepted September 13, 2016

Published December 19, 2016

DOI http://dx.doi.org/10.4238/gmr15047026

Copyright (C) 2016 The Authors. This is an open-access article distributed under the terms of the Creative Commons Attribution ShareAlike (CC BY-SA) 4.0 License.

\begin{abstract}
In this study, we compared the functional properties of endothelial progenitor cells (EPCs) derived from halfpipe-snowboarding athletes who train under hyperoxic conditions with those derived from normal subjects who lived under normoxic conditions. Peripheral bloodderived EPCs were isolated from both halfpipe-snowboarding athletes and normal humans. Cellular growth dynamics, lipoprotein transport, and gene expression of cultured EPCs were compared between the two groups of cells. Results indicate that cytoactivity of EPCs from athletes was higher than that of EPCs from control subjects. This study suggests that function of EPCs from snowboarding athletes may be better than
\end{abstract}

Genetics and Molecular Research 15 (4): gmr15047026 
that of EPCs from normal humans, which demonstrates the benefits of training under hyperoxic conditions.

Key words: Halfpipe snowboarding athletes; EPCs; Cytoactivity; Differentiation

\section{INTRODUCTION}

Endothelial progenitor cells (EPCs) are precursors of vascular endothelial cells (Asahara et al., 1997). EPCs originate from the bone marrow angioblast and umbilical vein endothelial cells, which together belong to a subgroup of hematopoietic stem cells (Spadaccio et al., 2010). Two sources of EPCs can be detected in vitro, early and late EPCs. While early EPCs display spindle-shaped, linear growth structures, late EPCs form cobblestone-like, oval shaped structures (Gulati et al., 2003; Bai et al., 2012). EPCs not only take part in vascularization during embryonic development, but also participate in postnatal vascularization and post-trauma reparative processes (Bonello et al., 2006). Therefore, EPCs hold extensive prospects for vascular tissue engineering as well as possible clinical applications in coronary artery diseases and wound healing (Gulati et al., 2003). Snowboarders are a special population of athletes who train under hyperoxic conditions for extended periods of time. The functions of various body systems, especially the respiratory and cardiovascular systems, are more efficient than those of their normal human counterparts who live under normoxic conditions. In this study, the specific functional properties of EPCs from halfpipe-snowboarding athletes were compared with that from normal subjects.

\section{MATERIAL AND METHODS}

\section{Blood collection}

Peripheral blood was sampled from healthy halfpipe-snowboarding athletes on the Chinese national team. This study was approved by the Harbin Institute of Physical Education Ethics Committees of the Human Movement Sciences Center. Informed written consent was obtained from each athlete prior to blood collection.

\section{Isolation and culture of endothelial progenitor cells}

Peripheral blood-derived mononuclear cells were harvested using $1.077 \mathrm{~g} / \mathrm{mL}$ Percoll solution (Sigma-Aldrich, St. Louis, MO, USA). The Percoll solution was slowly added into a centrifuge tube followed by $5 \mathrm{~mL}$ peripheral blood. The tube was centrifuged at $400 \mathrm{~g}$ for $20 \mathrm{~min}$. The white nebulous layer was collected and washed twice with DMEM, and centrifuged at $200 \mathrm{~g}$ for $5 \mathrm{~min}$. A cell suspension containing the majority of the EPCs was obtained using anti-CD34 antibody via flow cytometry. Cells were seeded on fibronectin-coated plastic plates in EGM-2MV medium, and cultured at $37^{\circ} \mathrm{C}$ in $5 \%$ $\mathrm{CO}_{2}$. Half of the media was replaced after 3 days, and media was then fully replaced once every 3 days. When cultured cells reached 70 to $80 \%$ confluence, they were passaged with $0.25 \%(\mathrm{w} / \mathrm{v})$ trypsin and subcultured at $1: 3$ ratio.

Genetics and Molecular Research 15 (4): gmr15047026 


\section{Growth dynamics of endothelial progenitor cells}

To assess changes in growth dynamics, EPCs from athletes and normal humans were seeded onn 24-well plates at a density of $1.0 \times 10^{4}$ cells/well, and cultured for 8 days. Cells were counted every day thereafter for up to 8 days. The mean cell counts determined in triplicate wells at each time point was used to plot growth curves. The population doubling time was also calculated using the following formula:

$$
\text { population doubling time }=(t-t 0) \lg 2 /(\lg N t-\lg N 0) \quad(\text { Equation } 1)
$$

where t0 is the starting culture time, $t$ is the time of culture termination, $\mathrm{N} 0$ is the initial cell numbers of the culture, and $\mathrm{Nt}$ is the total cell number at the end of culture period.

\section{Comparison of lipoprotein transport in endothelial progenitor cells from athletes and normal humans}

EPCs derived from athletes and normal humans were washed three times for $5 \mathrm{~min}$ each in PBS, and then incubated in media containing $12 \mathrm{mg} / \mathrm{mL}$ acetylated Dil low density lipoprotein for $4 \mathrm{~h}$ at $37^{\circ} \mathrm{C}$ and $5 \% \mathrm{CO}_{2}$. Cells were then washed three more times, fixed with $2 \%$ paraformaldehyde, and incubated for $1 \mathrm{~h}$ with FITC-Oxytropis lectin $1(10 \mathrm{mg} / \mathrm{mL})$ at room temperature. Cells were observed and analyzed using the Nikon TE-2000-E confocal microscope system.

\section{Real-time PCR}

The relative expression of EPC molecular markers in EPCs from athletes and normal humans was compared using real-time PCR. Total RNA was extracted from EPCs using Trizol (Invitrogen, USA). Isolated RNA was reverse transcribed and used as a template for 30 PCR cycles with the RNA PCR kit version 3.0 (TaKaRa, China). Real-time PCR was performed in $20-\mu \mathrm{L}$ reaction mixtures containing $10 \mu \mathrm{L}$ SYBR premix Ex Taq buffer (TaKaRa), $0.4 \mu \mathrm{L}$ ROX reference dye, $0.8 \mu \mathrm{M}$ forward and reverse primers (Table 1), $1 \mu \mathrm{L}$ cDNA template, and $7 \mu \mathrm{L} \mathrm{ddH_{2 }} \mathrm{O}$. The cycling parameter was as follows: $10 \mathrm{~s}$ at $95^{\circ} \mathrm{C}$ followed by 40 cycles of two-temperature cycling: $5 \mathrm{~s}$ at $95^{\circ} \mathrm{C}$ and $34 \mathrm{~s}$ at $60^{\circ} \mathrm{C}$. Each experiment was performed in duplicate on 96-well plates, and was repeated five times. Gene expression was detected on an ABI 7500 real-time PCR system (ABI, USA). The relative expression level of each gene was calculated by the $2^{-\Delta \Delta \mathrm{Ct}}$ method.

\section{RESULTS}

\section{Isolation and culture of endothelial progenitor cells}

Phase contrast micrographs of EPCs cultures are presented in Figure 1A, which shows the typical cobblestone morphology of late EPCs. No differences were observed between the cellular morphology of EPCs from either athletes or normal humans. EPCs from athletes were passaged 55 times and maintained in culture for 114 days with no sign of senescence

Genetics and Molecular Research 15 (4): gmr15047026 
or differentiation. However, EPCs from normal humans were only passaged 45 times and maintained in culture for 102 days before signs of senescence and differentiation were observed (Figure 1B).

Table 1. Primer sequences used for real-time PCR.

\begin{tabular}{|c|c|c|c|c|}
\hline Gene & Primer sequence & $\operatorname{Tm}\left({ }^{\circ} \mathrm{C}\right)$ & Cycle & Fragment size (bp) \\
\hline CD133 & $\begin{array}{l}\text { F 5'-GCCACCGCTCTAGATACTGC-3' } \\
\text { R 5'-TGTTGTGATGGGCTTGTCTA-3' }\end{array}$ & 60 & 40 & 172 \\
\hline Flk & $\begin{array}{l}\text { F 5'-AATACCAGTGGATGTGATGC-3' } \\
\text { R 5'-CTGGCATGGTCTTCTGTGAAG-3' }\end{array}$ & 60 & 40 & 166 \\
\hline vWF & $\begin{array}{l}\text { F 5'-CCCACCGGCGCCAAAAGAGA-3' } \\
\text { R 5'-CTGGTTTTCCTTCAGCTGGA-3' }\end{array}$ & 60 & 40 & 160 \\
\hline CD31 & $\begin{array}{l}\text { F 5'-GTCACAGAAGAGGATGAAGG-3' } \\
\text { R 5'-CACAGTCCGGCACGTAGGTG-3' }\end{array}$ & 60 & 40 & 104 \\
\hline GAPDH & $\begin{array}{l}\text { F 5'-TAAAGGCGAGATGGTGAAAG-3' } \\
\text { R 5'-ACGCTCCTGGAAGATAGTGAT-3' }\end{array}$ & 60 & 40 & 144 \\
\hline CD34 & $\begin{array}{l}\text { F 5'-AAGAAGGGTGGCAAGAAGCA-3' } \\
\text { R 5'-CTGGTGGTCACTGACACGATTT-3' }\end{array}$ & 60 & 40 & 131 \\
\hline
\end{tabular}
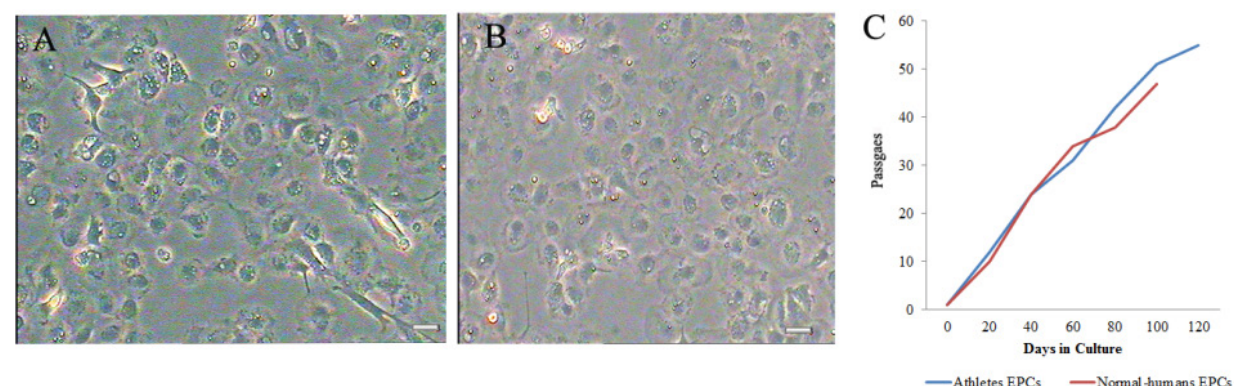

Figure 1. Micrograph observation of EPCs and culture in vitro. A. Slabstone-like appearance of EPCs isolated from athletes. B. Slabstone-like appearance of normal humans EPCs. C. Proliferation potential of athletes EPCs compared with normal-humans EPCs under EGM2-MV conditions. The population doubling time of cells were recorded at each passage.

\section{Growth dynamics of EPCs}

The growth curves demonstrated that EPCs from athletes had higher proliferation potential. After a period of latency (1-4 days), the cells grew in clusters. Cell growth then entered a logarithmic phase, and reached a plateau phase at approximately day 6 when cell numbers reached $6.3 \times 10^{6}$. The growth of EPCs from normal humans also reached the plateau phase at approximately day 6, and reached a total number of $5.21 \times 10^{6}$ cells (Figure 2A). Similarly, the population doubling time of EPCs from athletes was measured to be $33.12 \mathrm{~h}$ while that of normal subjects was $43.32 \mathrm{~h}$. (Figure 2B).

\section{Comparison of lipoprotein transport in EPCs}

EPCs have the ability to take up acetylated Dil low-density lipoprotein and FITCOxytropis lectin 1. Therefore, the capacity of EPCs from athletes and normal subjects to take up these two proteins was tested. The results showed a visible difference in lipoprotein transport between the two sources of EPCs (Figure 3).

Genetics and Molecular Research 15 (4): gmr15047026 

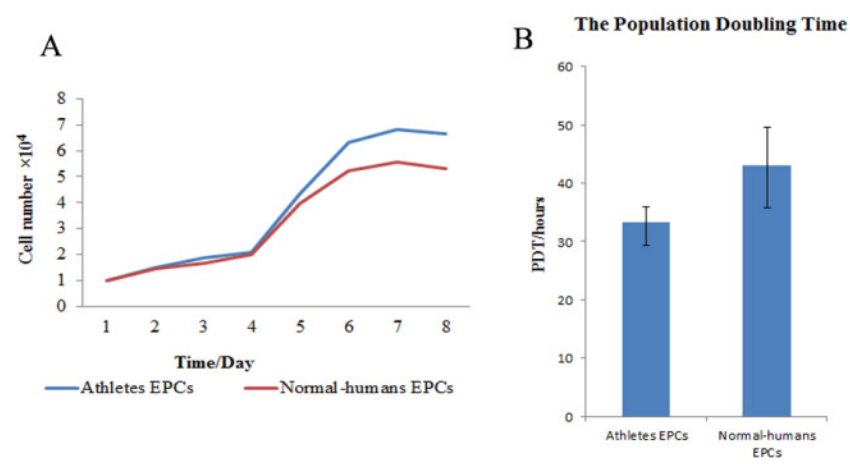

Figure 2. Growth curves of EPCs from both athletes and normal humans. A. Sigmoidal growth curves of EPCs from both athletes and normal humans. B. Population doubling time of EPCs from athletes and normal subjects.

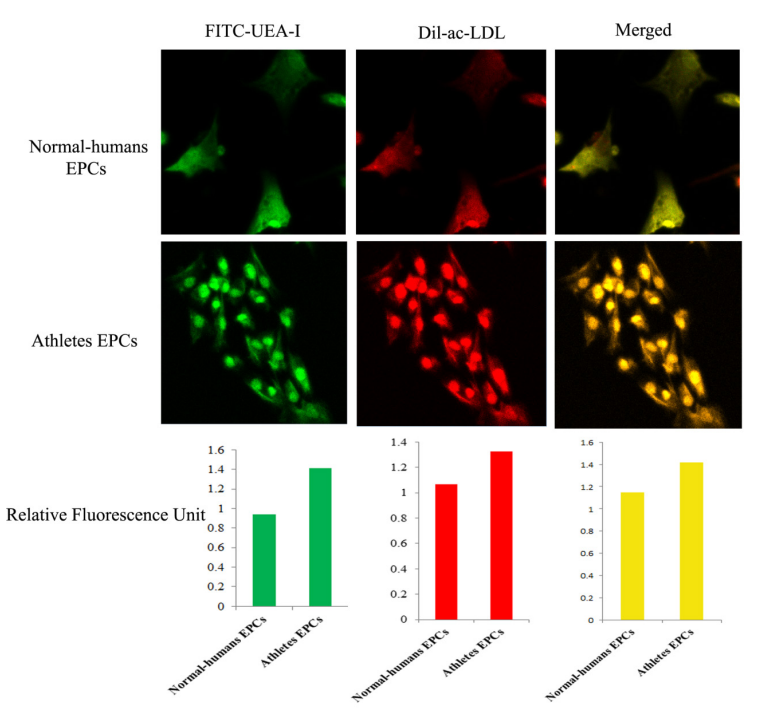

Figure 3. Uptake of Dil-ac-LDL and FITC-UEA-1 by EPCs. EPCs were incubated with DiL-ac-LDL and FITCUEA-1; uptake was assessed by the Nikon TE-2000-E confocal microscope analyses system. DiL-acLDL (red); FITC-UEA-1 (green), differentiated EPCs (yellow).

\section{Comparison of EPC molecular markers}

The relative expression of EPC molecular markers including fetal liver kinase (Flk), CD31, Von Willebrand factor (vWF), CD133, and CD34 in EPCs from the two groups was compared using real-time PCR. Results demonstrated that expression level of CD133 was lower in EPCs from athletes as compared with EPCs isolated from normal humans. On the contrary, the expression levels of Flk, CD31, and vWF were higher in EPCs from athletes as compared with those derived from normal humans. The expression level of CD34 was similar across the two groups (Figure 4).

Genetics and Molecular Research 15 (4): gmr15047026 

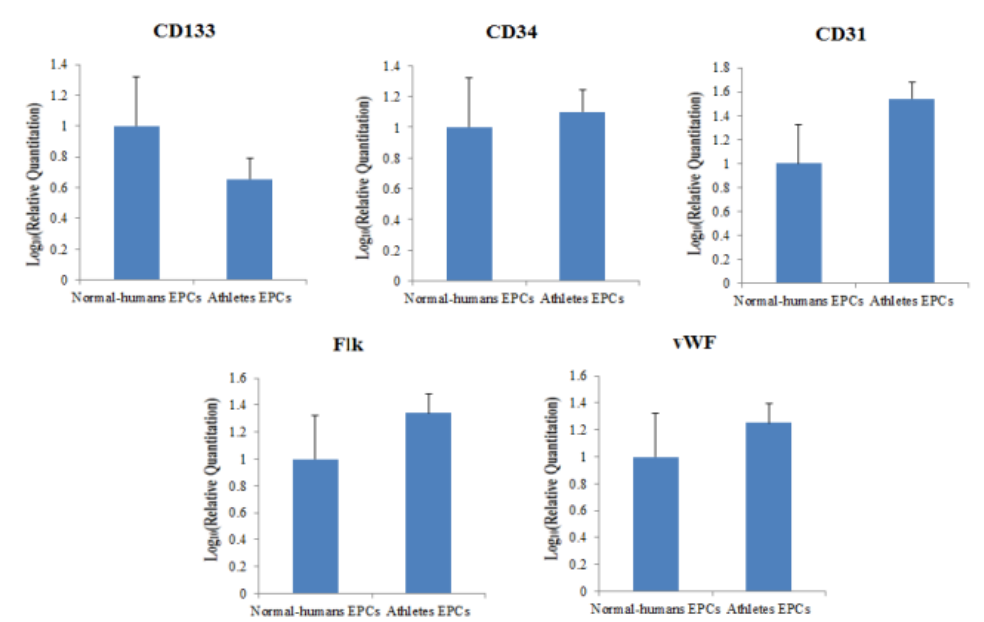

Figure 4. Relative gene expression profiles in EPCs from athletes and normal humans.

\section{DISCUSSION}

EPCs (also known as CD133+, VEGFR-2+, CD34+ cells) were first isolated from peripheral blood by Asahara et al. (1997) (Choi et al., 2014). These cells have the ability to differentiate into mature endothelial cells, and take part in angiogenesis. EPCs and hematopoietic stem cells originate from angioblasts located in the blood islands (Vasa et al., 2001; Shah et al., 2014). EPCs are usually isolated from umbilical cord blood or peripheral blood. It was proposed that EPCs could be used in cell therapies in diseases involving defects during angiogenesis, such as ischemia. Many experiments performed in different models confirmed that these cells were highly involved in the revascularization of ischemic tissues, and their specific tropism for the diseased tissues was very encouraging (Yamashita et al., 2000; Shintani et al., 2001; Strauer et al., 2002; Zhao et al., 2014). Low levels of circulating EPCs were thought to be related to increased cardiovascular risks, and could be a byproduct of a number of mechanisms. Various factors such as oxidative stress levels, nitric oxide activities, or other physiologic processes, could directly influence the mobilization or half-lives of EPCs (Hill et al., 2003; Zhang et al., 2006).

Snowboard athletes train for extended periods under high oxygen conditions, and therefore have developed more efficient circulatory functions, such as oxygen transport and revascularization, as compared with normal humans who live under normoxia. In this study, EPCs were isolated from peripheral blood of snowboarding athletes and normal humans. Results indicated that cell proliferation and lipoprotein transport was enhanced in EPCs from athletes as compared with EPCs from normal humans. It is known that endothelial cell surface heparan sulfate proteoglycans can hydrolyze triglycerides in lipoproteins, especially chylomicrons and very low-density lipoproteins. Lipoprotein is not synthesized by vascular endothelial cells, but is produced by the underlying adipocytes and myocytes. The physiological actions of lipoproteins are mediated primarily by the pool of lipoprotein located at the luminal surface of the endothelium. Therefore, the capacity for lipoprotein transport is an important function for endothelial cells. We found that the capacity for lipoprotein was higher in EPCs from athletes as compared with that in EPCs from normal humans. The

Genetics and Molecular Research 15 (4): gmr15047026 
results also demonstrated that expression level of CD133, a marker for progenitor cells, was lower in EPCs from normal humans as compared to that from athletes, which suggested that EPCs from athletes have higher tendencies for cell differentiation. CD133 (also known as $\mathrm{AC133}$ ) is a marker for hematopoietic stem cells and EPCs, and is gradually lost as EPCs differentiate into mature endothelial cells (Peichev et al., 2000; Schmeisser et al., 2001). vWF also functions as a specific marker for endothelial cell lineage. It is produced by endothelial cells, and is located in the cytoplasm of Weibel-Palade bodies (Feranil et al., 2005; Stamper et al., 2007). Therefore, vWF and Weibel-Palade bodies serve as specific markers for endothelial cell differentiation. Our results suggested that the EPCs from athletes were more inclined to differentiate into endothelial cells as compared with EPCs from normal humans.

\section{CONCLUSION}

In conclusion, we characterized the differences between two source EPCs, and have demonstrated that EPCs from snowboarding athletes had higher cytoactivity and capacity for differentiation as compared with EPCs from normal humans. This finding suggests that conditions of hyperoxia can enhance functions of EPCs.

\section{Conflicts of interest}

The authors declare no conflict of interest.

\section{ACKNOWLEDGMENTS}

Research supported by the Agricultural Science and Technology Innovation Program (cxgc-ias-01), the National Natural Science Foundation of China (Grant \#31472099), and the National Infrastructure of Animal Germplasm Resources (2016).

\section{REFERENCES}

Asahara T, Murohara T, Sullivan A, Silver M, et al. (1997). Isolation of putative progenitor endothelial cells for angiogenesis. Science 275: 964-967. http://dx.doi.org/10.1126/science.275.5302.964

Bai C, Hou L, Zhang M, Pu Y, et al. (2012). Characterization of vascular endothelial progenitor cells from chicken bone marrow. BMC Vet. Res. 8: 54.http://dx.doi.org/10.1186/1746-6148-8-54

Bonello L, Basire A, Sabatier F, Paganelli F, et al. (2006). Endothelial injury induced by coronary angioplasty triggers mobilization of endothelial progenitor cells in patients with stable coronary artery disease. J. Thromb. Haemost. 4: 979-981.http://dx.doi.org/10.1111/j.1538-7836.2006.01858.x

Choi JK, Moon KM, Jung SY, Kim JY, et al. (2014). Regular exercise training increases the number of endothelial progenitor cells and decreases homocysteine levels in healthy peripheral blood. Korean J. Physiol. Pharmacol. 18: 163-168. http://dx.doi.org/10.4196/kjpp.2014.18.2.163

Feranil JB, Isobe N and Nakao T (2005). Immunolocalization of von Willebrand factor and vascular endothelial growth factor during follicular atresia in the swamp buffalo ovary. J. Reprod. Dev. 51: 419-426. http://dx.doi.org/10.1262/ jird.17011

Gulati R, Jevremovic D, Peterson TE, Chatterjee S, et al. (2003). Diverse origin and function of cells with endothelial phenotype obtained from adult human blood. Circ. Res. 93: 1023-1025. http://dx.doi.org/10.1161/01. RES.0000105569.77539.21

Hill JM, Zalos G, Halcox JP, Schenke WH, et al. (2003). Circulating endothelial progenitor cells, vascular function, and cardiovascular risk. N. Engl. J. Med. 348: 593-600. http://dx.doi.org/10.1056/NEJMoa022287

Peichev M, Naiyer AJ, Pereira D, Zhu Z, et al. (2000). Expression of VEGFR-2 and AC133 by circulating human CD34(+) cells identifies a population of functional endothelial precursors. Blood 95: 952-958.

Genetics and Molecular Research 15 (4): gmr15047026 
Schmeisser A, Garlichs CD, Zhang H, Eskafi S, et al. (2001). Monocytes coexpress endothelial and macrophagocytic lineage markers and form cord-like structures in Matrigel under angiogenic conditions. Cardiovasc. Res. 49: 671680. http://dx.doi.org/10.1016/S0008-6363(00)00270-4

Shah QA, Tan X, Bi S, Liu X, et al. (2014). Differential characteristics and in vitro angiogenesis of bone marrow- and peripheral blood-derived endothelial progenitor cells: evidence from avian species. Cell Prolif. 47: 290-298. http:// dx.doi.org/10.1111/cpr.12111

Shintani S, Murohara T, Ikeda H, Ueno T, et al. (2001). Augmentation of postnatal neovascularization with autologous bone marrow transplantation. Circulation 103: 897-903.http://dx.doi.org/10.1161/01.CIR.103.6.897

Spadaccio C, Pollari F, Casacalenda A, Alfano G, et al. (2010). Atorvastatin increases the number of endothelial progenitor cells after cardiac surgery: a randomized control study. J. Cardiovasc. Pharmacol. 55: 30-38. http:// dx.doi.org/10.1097/FJC.0b013e3181c37d4d

Stamper IJ, Byrne HM, Owen MR and Maini PK (2007). Modelling the role of angiogenesis and vasculogenesis in solid tumour growth. Bull. Math. Biol. 69: 2737-2772. http://dx.doi.org/10.1007/s11538-007-9253-6

Strauer BE, Brehm M, Zeus T, Köstering M, et al. (2002). Repair of infarcted myocardium by autologous intracoronary mononuclear bone marrow cell transplantation in humans. Circulation 106: 1913-1918. http://dx.doi.org/10.1161/01. CIR.0000034046.87607.1C

Vasa M, Fichtlscherer S, Aicher A, Adler K, et al. (2001). Number and migratory activity of circulating endothelial progenitor cells inversely correlate with risk factors for coronary artery disease. Circ. Res. 89: E1-E7. http://dx.doi. org $/ 10.1161 / \mathrm{hh} 1301.093953$

Yamashita J, Itoh H, Hirashima M, Ogawa M, et al. (2000). Flk1-positive cells derived from embryonic stem cells serve as vascular progenitors. Nature 408: 92-96. http://dx.doi.org/10.1038/35040568

Zhang SJ, Zhang H, Wei YJ, Su WJ, et al. (2006). Adult endothelial progenitor cells from human peripheral blood maintain monocyte/macrophage function throughout in vitro culture. Cell Res. 16: 577-584. http://dx.doi.org/10.1038/ sj.cr.7310075

Zhao M, Wang XX and Wan WH (2014). Effects of the ginkgo biloba extract on the superoxide dismutase activity and apoptosis of endothelial progenitor cells from diabetic peripheral blood. Genet. Mol. Res. 13: 220-227. http://dx.doi. org/10.4238/2014.January.14.1

Genetics and Molecular Research 15 (4): gmr15047026 